\title{
GAYA PENGASUHAN OTORITER DAN PERMISIF SERTA TINGKAT STRES IBU SEBAGAI FAKTOR RISIKO GANGGUAN EMOSI DAN PERILAKU ANAK USIA SEKOLAH
}

\author{
Sarifudin $\left.^{1 *}\right)$, Dwi Hastuti², Megawati Simanjuntak ${ }^{2}$ \\ 1Program Studi IImu Keluarga dan Perkembangan Anak, Sekolah Pascasarjana, \\ IPB University, Bogor 16680, Indonesia \\ ${ }^{2}$ Departemen Ilmu Keluarga dan Konsumen, Fakultas Ekologi Manusia, \\ IPB University, Bogor 16680, Indonesia \\ *)E-mail: syaristomia@gmail.com
}

\begin{abstract}
Abstrak
Anak Indonesia saat ini sedang mengalami peningkatan risiko gangguan emosi dan perilaku. Hal ini ditunjukkan dengan banyaknya kasus anak yang berhadapan dengan hukum, kasus anak bidang pengasuhan, pendidikan, kesehatan dan napza, serta kasus anak dalam bidang pornografi dan cybercrime. Ibu melalui pengasuhan yang dilakukan serta faktor diri ibu dipercaya sebagai salah satu kunci penting untuk mencegah hal tersebut. Penelitian ini bertujuan untuk menganalisis pengaruh self-efficacy ibu, gaya pengasuhan, dan tingkat stres ibu terhadap gangguan emosi dan perilaku anak. Desain penelitian adalah cross sectional dengan lokasi penelitian dipilih secara purposive di salah satu sekolah dasar negeri di Kota Bogor. Teknik pemilihan sampel dilakukan secara quota sampling yang terdiri dari 50 anak laki-laki dan 50 anak perempuan sehingga total contoh adalah 100 anak dan selanjutnya akan menjadi responden penelitian bersama ibunya. Data dikumpulkan melalui wawancara ibu dan anak menggunakan kuesioner. Hasil penelitian menunjukkan bahwa gaya pengasuhan otoriter ibu, gaya pengasuhan permisif ibu, dan tingkat stres ibu berpengaruh terhadap gangguan emosi dan perilaku anak. Sementara itu, self-efficacy ibu dan gaya pengasuhan otoritatif ibu tidak berpengaruh terhadap gangguan emosi dan perilaku anak.
\end{abstract}

Kata kunci: gangguan perilaku anak, gangguan emosi anak, gaya pengasuhan ibu, self-efficacy ibu, tingkat stres ibu

\section{Authoritarian and Permissive Parenting and Maternal Stress as Risk Factors of Emotional and Behavioral Disorders of School-Age Children}

\begin{abstract}
Indonesian children are currently experiencing an increased risk of emotional and behavioral disorders. This is indicated by the many cases of children dealing with law; cases of children in the fields of care, education, health and drugs; and cases of children in the fields of pornography and cybercrime. Mothers through parenting practices and the mother's self factors are believed to be one of the important keys to preventing this. This study aims to analyze the influence of maternal self-efficacy, parenting style, and stress levels of the mother on emotional and behavioral disorders of children. The study design was cross-sectional with the research location chosen purposively in one of the state elementary schools in Bogor City. The sample selection technique was done by quota sampling consisting of 50 boys and 50 girls so that the total sample was 100 children and will then become research respondents with their mothers. Data were collected through mother and child interviews using a questionnaire. The results showed that the authoritarian parenting style of the mother, the permissive parenting style of the mother, and the stress level of the mother affected the emotional and behavioral disorders of the child. Meanwhile, maternal self-efficacy and the mother's authoritative parenting style do not affect children's emotional and behavioral disorders.
\end{abstract}

Keywords: behavioral disorders of children, emotional disorders of children, maternal parenting style, maternal self-efficacy, maternal stress level

\section{PENDAHULUAN}

Anak merupakan salah satu aset orang tua dan menjadi penerus generasi bangsa. Data BPS
(2016) memperlihatkan jumlah penduduk Indonesia sebanyak 258 juta jiwa, sepertiga diantaranya atau 32,2 persen adalah anakanak. Kondisi anak di Indonesia saat ini 
mengalami berbagai ancaman risiko gangguan emosi dan perilaku. Berdasarkan data Komisi Perlindungan Anak Indonesia (2015) terdapat peningkatan jumlah kasus anak setiap tahunnya; di antaranya terdapat 6.006 kasus anak yang berhadapan dengan hukum (kekerasan fisik, pembunuhan, pencurian, kecelakaan lalu lintas, penculikan, aborsi dan kepemilikan senjata tajam), 3.160 kasus anak dalam bidang pengasuhan, 1.764 kasus pada bidang pendidikan (tawuran pelajar, bullying, pungutan liar), 1.366 kasus dalam bidang kesehatan dan napza, dan 1.032 kasus bidang pornografi dan cybercrime (kejahatan seksual online, pornografi, dan media sosial). Sementara itu, Provinsi Jawa Barat merupakan peringkat kedua setelah DKI Jakarta dalam hal kekerasan terhadap anak. Tidak hanya kekerasan fisik tapi juga penyalahgunaan, eksploitasi, diskriminasi, dan pengabaian atas hak anak. Menurut data KPAl tahun 2018, kasus kekerasan anak Kota Bogor mulai dari kekerasan fisik, kekerasan verbal, sampai pada kekerasan seksual mengalami peningkatan pada tahun 2018 sebanyak 46 kasus dari tahun 2017 sebanyak 30 kasus. Dari jumlah kasus tersebut, 40 persen terjadi di kalangan remaja atau tingkat sekolah menengah (Kementerian Sosial, 2014).

Hal ini mengindikasikan jika anak rentan serta beresiko untuk mengalami gangguan emosi dan perilaku yang kurang sesuai sehingga membutuhkan peran keluarga untuk mengatasinya. Anak sebagai individu yang masih mengalami proses pembentukan emosi dan perilaku, membutuhkan peran keluarga dan lingkungan di sekitarnya. Menurut Hastuti (2015), faktor risiko pada anak tidak hanya ditentukan oleh faktor diri anak, tetapi juga faktor keluarga dan lingkungan eksternal keluarga.

Menurut Baumrind (1967), gaya pengasuhan dapat diidentifikasi dalam empat dimensi penting yaitu strategi pendisiplinan, kehangatan dan perawatan, gaya komunikasi, serta harapan terhadap kedewasaan dan kontrol. Dari ke empat dimensi tersebut, Baumrind membagi gaya pengasuhan menjadi tiga tipe, yaitu authoritative/otoritatif (menekankan pada tuntutan yang beralasan), authoritarian/otoriter (menuntut kepatuhan), dan permissive/permisif (menuruti keinginan anak). Baumrind (1966) menyatakan bahwa gaya pengasuhan yang terbaik yang dapat dilakukan oleh orang tua adalah gaya pengasuhan otoritatif, sementara orang tua dengan gaya pengasuhan otoriter dan permisif bisa menjadikan anak pemarah dan agresif. Hasil penelitian Zhou, Eisenberg,
Wang, dan Reiser (2004) menunjukkan bahwa anak yang diasuh dengan gaya pengasuhan otoriter akan memiliki kemampuan sosial dan kepercayaan diri yang rendah. Anak yang diasuh dengan gaya pengasuhan otoritatif akan terhindar dari perbuatan kriminal, memiliki kompetensi sosial yang baik, dan memiliki tujuan; sementara anak yang diasuh dengan gaya pengasuhan permisif cenderung untuk melakukan tindakan kriminal ketika remaja (Okorodudu, 2010).

Gaya pengasuhan positif yang cenderung otoritatif merupakan faktor penting untuk membentuk perilaku anak, akan tetapi rendahnya self-efficacy dan tingkat stres orang tua sering menjadi faktor penghambat untuk membentuk perilaku anak. Bandura (1977) mendefinisikan self-efficacy sebagai keyakinan tentang kemampuan yang dimiliki untuk mengatur dan melakukan serangkaian tindakan yang diperlukan dalam mencapai keinginannya. Lebih lanjut, self-efficacy orang tua menjadi faktor pelindung terhadap permasalahan anak dan remaja (Jones \& Prinz, 2005; Page, Wilhelm, Gamble, \& Card, 2010) sehingga penting bagi orang tua memiliki keyakinan tersebut. Coleman dan Karraker (1998) mengungkapkan self-efficacy orang tua yang tinggi terkait dengan pola asuh strategi dan perilaku yang positif. Self-efficacy orang tua berkaitan dengan distres orang tua (Hastings \& Brown, 2002; Scheel \& Rieckmann, 1998; Shumow \& Lomox, 2002) dan perilaku anak (Teti, O'Connell, \& Reiner,1996; Woolfson, Taylor, \& Mooney, 2011).

Stres merupakan keseluruhan proses yang meliputi stimulasi, kejadian, peristiwa, dan respon serta interpretasi individu yang menyebabkan timbulnya ketegangan di luar kemampuan seseorang untuk mengatasinya (Rice, 1992). Stres dalam keluarga pada tahun pertama anak dapat dianggap sebagai faktor risiko yang berdampak pada semua aspek karena secara signifikan mengganggu kesehatan psikologis dan fungsi orang tua dalam membangun interaksi, perkembangan emosi, dan perilaku anak (Anthony et al., 2005; Coyl, Roggman, \& Newland, 2002; Crnic, Gaze, \& Hoffman, 2005; Deater-Deckard, 2005; Dopke, Lundahl, Dunsterville, \& Lovejoy, 2003). Rothbart (2004) menjelaskan bahwa pola asuh dan kemampuan mengelola emosi atau stres orang tua memengaruhi emosi dan perilaku anak. Penelitian Yeo dan Teo (2013) mengungkapkan bahwa tingkat stres yang dialami oleh seorang ibu akan berpengaruh terhadap perilaku anak. 
Gangguan emosi dan perilaku anak mengacu pada suatu kondisi dengan tanggapan emosi atau perilaku seorang individu sangat berbeda dari norma-norma yang umumnya diterima, sesuai dengan usia, etnis, atau budaya (Forness \& Knitzer, 1990). Salah satu faktor yang turut berperan dalam perkembangan perilaku dan emosi pada anak adalah pola asuh orang tua. Orang tua memiliki hubungan yang dekat dan waktu yang relatif lama dalam bersosialisasi dengan anak sehingga kemampuan orang tua dalam memberikan rangsangan atau stimulus memengaruhi kondisi emosi anak (Isfandari \& Suhardi, 1997).

Penelitian pada budaya barat telah menemukan bahwa anak-anak yang mengalami pelecehan dan kekerasan dalam kehidupan sehari-hari melalui pengasuhan lebih cenderung menampilkan masalah perilaku (Hickman, 2013). Misalnya, bentuk kekerasan yang dilaporkan meningkatkan risiko eksternal dan internal masalah perilaku (Braza et al., 2013; Mäntymaa et al., 2012). Benjet, Borges, dan Medina-Mora (2010) mengungkapkan bahwa anak-anak dengan masa kanak-kanak yang diabaikan oleh orang tua, mengalami kekerasan fisik atau seksual dilaporkan memiliki masalah gangguan emosi dan perilaku dalam kehidupan di masa depan, seperti masalah yang terkait dengan tingkat stres yang tinggi, depresi, sadisme, atau bahkan radikalisme pada kehidupan remaja dan dewasa. Hasil penelitian Penza, Heim, dan Nemeroff (2003) menemukan bahwa stres yang terjadi pada masa dewasa ada hubungannya dengan pengalaman perilaku yang menyakitkan pada masa kanak-kanak. Di Indonesia, KPAI (2015) melaporkan bahwa sebesar 78,3 persen anak menjadi pelaku kekerasan dan sebagian besar karena pernah menjadi korban kekerasan sebelumnya atau pernah melihat kekerasan dilakukan kepada anak lain dan menirunya.

Beberapa penelitian sebelumnya telah membuktikan bahwa peran orang tua melalui pengasuhan dapat memengaruhi emosi dan perilaku anak. Hasil penelitian Baker, Perilla, dan Norris (2001) mengungkapkan bahwa keadaan stres berkaitan dengan pengasuhan dan ketidakmampuan yang dimiliki orang tua. Penelitian Rothbart (2004) menjelaskan bahwa pola asuh dan kemampuan mengelola emosi atau stres orang tua memengaruhi emosi dan perilaku anak. Penelitian Lorber dan Egeland (2011) menjelaskan bahwa pola asuh yang dimiliki orang tua dan riwayat keluarga dengan gangguan dan kekerasan fisik sangat memengaruhi emosi dan perilaku anak. Berdasarkan uraian tersebut, peran orang tua sangat penting sebagai lingkungan pertama dalam mendidik anak. Namun kurangnya penelitian tentang gangguan emosi dan perlaku anak yang dikaitkan dengan self-efficacy orang tua, gaya pengasuhan, dan tingkat stres ibu menjadikan penelitian ini sangat penting dilakukan. Oleh karena, tujuan penelitian ini adalah untuk mengidentifikasi karakteristik keluarga, karakteristik anak, self-efficacy ibu, gaya pengasuhan ibu, tingkat stres ibu dan gangguan emosi dan perilaku anak usia sekolah dan menganalisis pengaruh selfefficacy, gaya pengasuhan dan tingkat stres ibu terhadap gangguan emosi dan perilaku anak usia sekolah.

\section{METODE}

Penelitian ini menggunakan desain cross sectional study untuk mengetahui hubungan dan pengaruh dari tiap variabel penelitian yang dilakukan pada satu titik dan waktu yang bersamaan. Desain penelitian ini dipilih berdasarkan pertimbangan waktu dan biaya penelitian. Penelitian dilakukan di sekolah dasar Pengadilan 5, Kecamatan Bogor Tengah, Kota Bogor, dengan pertimbangan bahwa Kota Bogor mengalami peningkatan dalam permasalahan anak setiap tahunnya. Menurut data rencana induk pembangunan pendidikan tahun 2009, Bogor Tengah merupakan kecamatan yang menempati urutan pertama rasio murid terhadap sekolah. Sementara itu, selain berada dipusat Kota Bogor, SD Pengadilan 5 merupakan salah satu SD dengan jumlah siswa terbanyak dan orang tuanya memiliki latar belakang pendidikan, sosial, ekonomi dan budaya yang relatif beragam (heterogen).

Populasi penelitian ini adalah anak sekolah dasar yakni usia 7 sampai 9 tahun atau kelas I sampai kelas III yang bersekolah di SD Pengadilan 5, Kecamatan Bogor Tengah, Kota Bogor. Hal ini dikarenakan usia 7 sampai 9 tahun merupakan usia transisi anak dari lingkungan keluarga mengenal lingkungan sekolah. Jumlah populasi dalam penelitian adalah sebanyak 152 anak. Pengambilan responden dilakukan secara quota sampling yang terdiri dari 50 anak laki-laki dan 50 anak perempuan sehingga total responden adalah 100 anak. Kriteria responden adalah anak berumur 7 sampai 9 tahun, memiliki ibu, dan baik ibu maupun anak bersedia untuk menjadi responden penelitian.

Data primer yang dikumpulkan dalam penelitian ini meliputi karakteristik keluarga (usia ibu, pendidikan ibu, status pekerjaan ibu, 
pendapatan dan besar keluarga), karakteristik anak (usia dan jenis kelamin), self-efficacy ibu, gaya pengasuhan ibu, tingkat stres ibu, dan gangguan emosi dan perilaku anak. Data primer diperoleh dengan menggunakan kuesioner terstruktur.

Self-efficacy ibu adalah tinggi rendahnya keyakinan ibu responden dalam menguasai situasi dan menghasilkan hasil (outcome) yang positif. Self-efficacy ibu diukur berdasarkan perilaku anak pada saat dilakukan penelitian berdasarkan laporan dari ibunya. Kuesioner self-efficacy ibu dimodifikasi dari Child Adjustment and Parent Efficacy Scale: Development and Initial Validation of a Parent Report Measure (Morawska, Sanders, Haslam, Filus, \& Fletcher, 2014). Kuesioner asli sebanyak 30 pertanyaan. Setelah dimodifikasi dan dilakukan uji coba instrumen, penelitian ini menggunakan 20 pertanyaan untuk menilai perilaku anak dengan nilai Cronbach's alpha 0,967 , dan 20 pertanyaan untuk menilai selfefficacy ibu dengan nilai Cronbach's alpha 0,967 . Skala yang digunakan untuk mengukur perilaku anak adalah skala Likert 0 sampai 3 (0 = tidak pernah, 1 = jarang, 2 = sering, dan 3 = selalu). Sementara itu, skala yang digunakan mengukur self-efficacy ibu adalah skala Likert 1 sampai 10 (1 = sangat tidak yakin dengan kemampuannya, sampai $10=$ sangat yakin dengan kemampuannya).

Gaya -engasuhan ibu adalah cara yang dilakukan oleh ibu responden dalam berinteraksi dengan anaknya. Kuesioner gaya pengasuhan ibu dimodifikasi dari parenting style questionnaire (Robinson, Mandleco, Olsen, \& Hart, 1995). Kuesioner gaya pengasuhan ibu sebanyak 30 pertanyaan, terdiri dari 13 pertanyaan untuk menilai gaya pengasuhan otoritatif dengan nilai Cronbach's alpha 0,947, 13 pertanyaan untuk menilai gaya pengasuhan otoriter dengan nilai Cronbach's alpha 0,918, dan 4 pertanyaan untuk menilai gaya pengasuhan permisif dengan nilai Cronbach's alpha 0,873. Skala yang digunakan adalah skala Likert 1 sampai 5 (1) tidak pernah, 2 = jarang, 3 = kadang-kadang, 4 = sering, dan 5 = selalu)

Tingkat stres ibu adalah tinggi rendahnya tekanan yang dialami ibu responden, baik secara emosi maupun mental. Kuesioner tingkat stres ibu dimodifikasi dari The Kessler10 (Kessler et al., 2002). Kuesioner tingkat stres ibu sebanyak 10 pertanyaan dengan nilai Cronbach's alpha 0,972. Skala yang digunakan adalah skala Likert 1 sampai 5 (1 = tidak pernah, 2 = jarang, 3 = kadang-kadang, $4=$ sering, dan 5 = selalu).

Gangguan emosi dan perilaku anak adalah kesulitan yang dialami anak dalam penyesuaian diri dan bertingkah laku tidak sesuai dengan norma-norma yang berlaku dalam lingkungan kelompok usia maupun masyarakat pada umumnya. Kuesioner gangguan emosi dan perilaku anak dimodifikasi dari the strengths and difficulties questionnaire a pilot study on the validity of the self-report version (Goodman, Meltzer, \& Bailey, 2003). Kuesioner asli sebanyak 25 pertanyaan dan 5 dimensi. Setelah dimodifikasi dan dilakukan uji coba instrumen, penelitian ini menggunakan 17 pertanyaan untuk 4 dimensi, terdiri dari 3 pertanyaan untuk menilai hyperactivity dengan nilai Cronbach's alpha $0,916,5$ pertanyaan untuk menilai emotional symptoms dengan nilai Cronbach's alpha 0,850, 5 pertanyaan untuk menilai conduct problems dengan nilai Cronbach's alpha 0,877, dan 4 pertanyaan untuk menilai peer problems dengan nilai Cronbach's alpha 0,798 yang menggambarkan emosi dan perilaku negatif yang mungkin dimiliki oleh anak. Skala yang digunakan adalah skala Likert 0 sampai 2 ( $0=$ tidak benar, 1 = agak benar, dan 2 = pasti benar).

Masing-masing variabel diberikan skor, selanjutnya total skor ditransformasikan menjadi skor indeks. Skor indeks yang dicapai dikategorikan berdasarkan rentang kelas.Tiga kategori yang digunakan, yaitu rendah, sedang, dan tinggi. Cut off yang digunakan adalah Bloom's cut-off point dari Yimer, Abera, Mulu, dan Bezabih (2014) untuk mengategorikan variabel self-efficacy, gaya pengasuhan, tingkat stres ibu, dan gangguan emosi dan perilaku anak, dengan nilai cut-off yang digunakan adalah rendah $(0,00-60,0)$, sedang $(60,0-80,0)$, dan tinggi $(80,0-100,0)$.

Data yang dikumpulkan melalui kuesioner, kemudian diolah dan dianalisis melalui Microsoft Excel, Statistical Package for the Social Sience (SPSS) dan smart Partial Least Square (PLS) techniques. Proses pengolahan data meliputi editing, coding, entry, scoring, dan analisis. Pengolahan data dilakukan dengan menggunakan analisis deskriptif dan analisis inferensia. Analisis deskriptif digunakan untuk mengidentifikasi rata-rata, standar deviasi, nilai maksimum dan nilai minimum dari karakteristik ibu, karakteristik anak, self-efficacy ibu, gaya pengasuhan ibu, tingkat stres ibu, dan gangguan emosi dan perilaku anak. Analisis inferensia yang digunakan adalah SPSS dan 
Structural Equation Model (SEM) menggunakan Smart Partial Least Square (PLS) techniques.

\section{HASIL}

Hasil penelitian ini menunjukkan bahwa ratarata usia ibu adalah 38,1 tahun dan tersebar di rentang usia $21-40$ tahun $(70,0 \%)$. Selain itu, lebih dari setengah ibu responden (57,0\%) bekerja. Rata-rata besar keluarga 4 orang dan terkategori keluarga kecil; dan setengah ibu memiliki tingkat pendidikan adalah tamat SMA/sederajat $(52,0 \%)$ sedangkan ibu dengan pendidikan pascasarjana (S2) hanya 1,0 persen. Rata-rata pendapatan per kapita keluarga Rp701.750,1 dengan 89,0 persen di atas angka garis kemiskinan Kota Bogor. Ratarata usia anak secara keseluruhan adalah 7,8 tahun, dengan persentase anak usia 7 tahun sebesar 43,0 persen, usia 8 tahun sebesar 36,0 persen, dan usia 9 tahun sebesar 21,0 persen. Jenis kelamin anak dalam penelitian ini adalah jumlah anak perempuan sama dengan anak laki-laki (Tabel 1).

Tabel 1 Sebaran responden berdasarkan karakteristik keluarga dan karakteristik anak

\begin{tabular}{|c|c|c|}
\hline Karakteristik & Kategori & $\begin{array}{l}\text { Persentase } \\
(\%)\end{array}$ \\
\hline \multicolumn{3}{|c|}{ Karakteristik keluarga } \\
\hline \multirow[t]{3}{*}{ Usia ibu } & $21-40$ tahun & 70,0 \\
\hline & $41-65$ tahun & 30,0 \\
\hline & $66-74$ tahun & 0,0 \\
\hline \multirow{6}{*}{$\begin{array}{l}\text { Pendidikan } \\
\text { ibu }\end{array}$} & Tamat SD & 2,0 \\
\hline & Tamat SMP & 12,0 \\
\hline & Tamat SMA & 52,0 \\
\hline & Tamat Diploma & 11,0 \\
\hline & Tamat S1 & 22,0 \\
\hline & Tamat S2 & 1,0 \\
\hline \multirow{2}{*}{$\begin{array}{l}\text { Status } \\
\text { pekerjaan ibu }\end{array}$} & Bekerja & 57,0 \\
\hline & Tidak bekerja & 43,0 \\
\hline \multirow{3}{*}{$\begin{array}{l}\text { Besar } \\
\text { keluarga }\end{array}$} & Kecil $(\leq 4)$ & 74,0 \\
\hline & Sedang $(5-7)$ & 26,0 \\
\hline & Besar $(\geq 8)$ & 0,0 \\
\hline \multirow{3}{*}{$\begin{array}{l}\text { Pendapatan } \\
\text { perkapita } \\
\text { keluarga }\end{array}$} & $\geq \mathrm{Rp} 416.779 /$ perbulan & \\
\hline & & \\
\hline & $<$ Rp416.779/ perbulan & 11,0 \\
\hline \multicolumn{3}{|c|}{ Karakteristik anak } \\
\hline \multirow[t]{3}{*}{ Usia anak } & 7 tahun & 43,0 \\
\hline & 8 tahun & 36,0 \\
\hline & 9 tahun & 21,0 \\
\hline \multirow[t]{2}{*}{$\begin{array}{l}\text { Jenis } \\
\text { kelamin anak }\end{array}$} & Laki-laki & 50,0 \\
\hline & Perempuan & 50,0 \\
\hline
\end{tabular}

\section{Self-efficacy lbu}

Pada penelitian ini kondisi perilaku negatif anak yang dipersepsikan ibu terkategori tinggi, sementara self-efficacy yang dimiliki ibu dalam kategori rendah. Hal ini disebabkan karena kondisi anak yang sering bertingkah pada waktu makan, menolak melakukan pekerjaan di sekitar rumah, bahkan kasar menjawab pertanyaan ibunya sehingga memengaruhi keyakinan ibu untuk mengubah perilaku anak. Kondisi perilaku negatif anak dapat dilihat berdasarkan data sebaran kategori perilaku anak yang menunjukkan bahwa perilaku negatif anak dengan skala tinggi sebesar 38,0 persen, kondisi anak dalam skala sedang 37,5 persen dan kondisi anak dalam skala rendah sebanyak 25,0 persen. Self-efficacy yang dimiliki ibu terkategori rendah, yaitu sebesar 95,0 persen, self-efficacy ibu dengan kategori sedang sebesar 4,0 persen dan hanya 1,0 persen ibu yang memiliki self-efficacy dengan kategori tinggi (Tabel 2).

\section{Gaya Pengasuhan}

Berdasarkan penelitian ini, sebagian besar gaya pengasuhan yang diterapkan ibu adalah gaya pengasuhan otoritatif, di samping ibu juga menerapkan gaya pengasuhan otoriter dan gaya pengasuhan permisif. Hasil penelitian menunjukan bahwa sebagian besar ibu memperhatikan perasaan dan kebutuhan anak serta memperlakukan anak sebagai anggota keluarga. Disamping itu, terdapat ibu yang sering mengancam anak sebagai bentuk hukuman, sangat marah bahkan memukul anak jika melakukan kesalahan, dan memanjakan anak. Hal ini dapat dilihat berdasarkan kategori dari masing-masing gaya pengasuhan ibu yaitu ibu yang menerapkan gaya pengasuhan otoritatif dalam mengasuh anak dengan kategori tinggi sebesar 61,0 persen, ibu yang menerapkan gaya pengasuhan otoritatif dengan kategori sedang 30,0 persen dan hanya 9,0 persen ibu yang menerapkan gaya pengasuhan otoritatif kategori rendah. Ibu yang menerapkan gaya pengasuhan otoriter dengan kategori tinggi sebesar 37,0 persen, ibu yang menerapkan gaya pengasuhan otoriter dengan kategori sedang 33,0 persen dan hanya 30,0 persen ibu yang menerapkan gaya pengasuhan otoriter dengan kategori rendah. Sementara itu, ibu yang menerapkan gaya pengasuhan permisif dengan kategori tinggi sebesar 42,0 persen, ibu yang menerapkan gaya pengasuhan permisif dengan kategori sedang 31,0 persen dan hanya 27,0 persen ibu yang menerapkan gaya pengasuhan permisif dengan kategori rendah (Tabel 2). 
Tabel 2 Sebaran responden berdasarkan self efficacy, gaya pengasuhan, tingkat stres ibu dan gangguan emosi dan perilaku anak serta nilai statistik indeks setiap variabel

\begin{tabular}{|c|c|c|c|c|c|}
\hline \multirow[b]{2}{*}{$\begin{array}{c}\text { Variabel / } \\
\text { dimensi }\end{array}$} & \multicolumn{3}{|c|}{ Kategori } & \multicolumn{2}{|c|}{ Nilai statistik indeks } \\
\hline & $\begin{array}{c}\text { Renda } \\
\text { h } \\
(00,0- \\
60,0)\end{array}$ & $\begin{array}{c}\text { Sedan } \\
g \\
(60,0- \\
80,0)\end{array}$ & $\begin{array}{c}\text { Tinggi } \\
(80,0- \\
100,0 \\
)\end{array}$ & $\begin{array}{c}\text { Minimum- } \\
\text { Maksimu } \\
\mathrm{m}\end{array}$ & $\begin{array}{c}\text { Rata-rata } \\
\pm \mathrm{SD}\end{array}$ \\
\hline \multicolumn{6}{|c|}{ Self-efficacy ibu } \\
\hline $\begin{array}{l}\text { Kondisi } \\
\text { anak }\end{array}$ & 25,0 & 37,0 & 38,0 & $1,0-100,0$ & $65,5 \pm 22,8$ \\
\hline $\begin{array}{l}\text { Self-efficacy } \\
\text { ibu }\end{array}$ & 95,0 & 4,0 & 1,0 & $9,0-100,0$ & $47,1 \pm 11,4$ \\
\hline \multicolumn{6}{|c|}{ Gaya pengasuhan ibu } \\
\hline Otoritatif & 9,0 & 30,0 & 61,0 & $\begin{array}{r}11,0- \\
100,0\end{array}$ & - $81,4 \pm 14,9$ \\
\hline Otoriter & 30,0 & 33,0 & 37,0 & $\begin{array}{r}13,0- \\
100,0\end{array}$ & $65,3 \pm 22,4$ \\
\hline Permisif & 27,0 & 31,0 & 42,0 & $\begin{array}{r}18,0- \\
100,0 \\
\end{array}$ & $67,6 \pm 21,7$ \\
\hline \multicolumn{6}{|c|}{ Tingkat stres ibu } \\
\hline $\begin{array}{l}\text { Tingkat } \\
\text { stres ibu }\end{array}$ & 31,0 & 33,0 & 36,0 & $\begin{array}{l}15,0- \\
100,0\end{array}$ & $63,7 \pm 24,5$ \\
\hline \multicolumn{6}{|c|}{ Gangguan emosi dan perilaku anak } \\
\hline $\begin{array}{l}\text { Hyperactivit } \\
y\end{array}$ & 67,0 & 33,0 & 0,0 & $0,0-60,0$ & $37,6 \pm 19,3$ \\
\hline $\begin{array}{l}\text { Emotional } \\
\text { symptoms }\end{array}$ & 49,0 & 38,0 & 13,0 & $0,0-100,0$ & $55,3 \pm 28,7$ \\
\hline $\begin{array}{l}\text { Conduct } \\
\text { problems }\end{array}$ & 65,0 & 33,0 & 2,0 & $0,0-100,0$ & $43,7 \pm 23,9$ \\
\hline $\begin{array}{l}\text { Peer } \\
\text { problems }\end{array}$ & 68,0 & 32,0 & 0,0 & $0,0-80,0$ & $40,2 \pm 24,7$ \\
\hline $\begin{array}{l}\text { Gangguan } \\
\text { emosi dan } \\
\text { perilaku } \\
\text { anak }\end{array}$ & 73,0 & 27,0 & 0,0 & $2,5-80,0$ & $44,6 \pm 19,5$ \\
\hline
\end{tabular}

\section{Tingkat Stres Ibu}

Tingkat stres orang tua merupakan dimensi penting dalam perkembangan emosi dan perilaku anak karena semakin tinggi tingkat stres orang tua dengan manajemen stres yang tidak baik akan memengaruhi pengasuhan yang beresiko terhadap emosi dan perilaku anak.

Hasil penelitian menunjukkan bahwa ibu memiliki stres dan tekanan hidup yang tinggi yang ditandai dengan sering merasa tertekan, sering gelisah, putus asa bahkan merasa dirinya tidak berharga. Hal ini dapat dilihat berdasarkan sebaran kategori tingkat stres ibu yaitu ibu dengan kategori tingkat stres yang tinggi sebesar 36,0 persen, ibu dengan kategori tingkat stres yang sedang sebesar 33,0 persen, dan hanya 31,0 persen ibu yang memiliki kategori tingkat sres yang rendah (Tabel 2).

\section{Gangguan Emosi dan Perilaku Anak}

Gangguan emosi dan perilaku anak adalah ketidakmampuan anak untuk menyesuaikan diri dan berperilaku sesuai dengan norma-norma yang berlaku pada lingkungan kelompok usia maupun masyarakat pada umumnya. Hasil penelitian menemukan bahwa anak dalam penelitian ini menunjukkan gangguan emosi dan perilaku terkategori rendah, artinya hanya sebagian kecil anak yang menunjukkan gejala hyperactivity seperti tidak bisa duduk diam dalam waktu yang lama dan selalu gelisah atau merasa sulit berkonsentrasi. Selain itu, hanya sebagian kecil anak yang menunjukkan gejala emosional seperti sering sakit kepala, khawatir, sedih, kurang percaya diri atau mudah takut. Hasil penelitian juga menunjukkan hanya sebagian kecil anak yang menunjukkan masalah kehilangan kontrol terhadap emosi, seperti berkelahi dengan anak-anak lain, berbohong atau dituduh curang dan mencuri.

Tabel 3 Hasil dekomposisi pengaruh karakteristik ibu, karakteristik anak, self-efficacy ibu, gaya pengasuhan ibu, dan tingkat stres ibu terhadap gangguan emosi dan perilaku anak

\begin{tabular}{|c|c|c|c|}
\hline Variabel & $\begin{array}{l}\text { Direct } \\
\text { effects }\end{array}$ & $\begin{array}{l}\text { ndirect } \\
\text { sffects }\end{array}$ & $\begin{array}{l}\text { Total } \\
\text { effects }\end{array}$ \\
\hline \multicolumn{4}{|l|}{$\begin{array}{l}\text { Self-efficacy } \\
\left(\mathrm{R}^{2}=0,079\right)\end{array}$} \\
\hline $\begin{array}{l}\text { Karakteristik } \\
\text { keluarga }\end{array}$ & 0,317 & & 0,317 \\
\hline Karakteristik anak & 0,054 & & 0,054 \\
\hline \multicolumn{4}{|l|}{$\begin{array}{l}\text { Gaya pengasuhan } \\
\text { ibu }\left(R^{2}=0,525\right)\end{array}$} \\
\hline $\begin{array}{l}\text { Karakteristik } \\
\text { keluarga }\end{array}$ & 0,221 & 0,530 & 0,642 \\
\hline Karakteristik anak & 0,742 & 0,051 & 0,201 \\
\hline Tingkat stres ibu & $0,000^{* *}$ & & $0,000^{* *}$ \\
\hline Self-efficacy ibu & 0,125 & & 0,125 \\
\hline \multicolumn{4}{|l|}{$\begin{array}{l}\text { Tingkat stres ibu } \\
\left(R^{2}=0,056\right)\end{array}$} \\
\hline $\begin{array}{l}\text { Karakteristik } \\
\text { keluarga }\end{array}$ & 0,633 & & 0,633 \\
\hline Karakteristik anak & 0,066 & & 0,066 \\
\hline \multicolumn{4}{|c|}{ Gangguan emosi dan perilaku anak $\left(\mathrm{R}^{2}=0,823\right)$} \\
\hline $\begin{array}{l}\text { Karakteristik } \\
\text { keluarga }\end{array}$ & & 0,934 & 0,934 \\
\hline Karakteristik anak & & 0,087 & 0,087 \\
\hline Self-efficacy ibu & 0,096 & & 0,096 \\
\hline $\begin{array}{l}\text { Gaya pengasuhan } \\
\text { otoritatif ibu }\end{array}$ & 0,077 & & 0,077 \\
\hline $\begin{array}{l}\text { Gaya pengasuhan } \\
\text { otoriter ibu }\end{array}$ & $0,000^{* *}$ & & $0,000^{* *}$ \\
\hline $\begin{array}{l}\text { Gaya pengasuhan } \\
\text { permisif ibu }\end{array}$ & $0,000^{\star \star}$ & & $0,000^{\star \star}$ \\
\hline Tingkat stres ibu & $0,000^{\star *}$ & $0,000^{* *}$ & $0,000^{* *}$ \\
\hline
\end{tabular}


Disamping itu, hanya sebagian kecil anak yang menunjukkan masalah hubungan dengan teman sebayanya, seperti suka menyendiri atau sering digertak teman-temannya. Hal tersebut terlihat dari setiap kategori pada setiap dimensi gangguan emosi dan perilaku anak. Pada dimensi hyperactivity menunjukkan bahwa anak dengan gangguan emosi dan perilaku kategori rendah sebesar 67,0 persen, anak dengan gangguan emosi dan perilaku kategori sedang
33,0 persen, dan tidak ditemukan anak yang mengalami gangguan emosi dan perilaku dengan kategori tinggi. Pada dimensi emotional symptoms menunjukkan bahwa anak dengan gangguan emosi dan perilaku kategori rendah sebesar 49,0 persen, anak dengan gangguan emosi dan perilaku kategori sedang 38,0 persen dan hanya 13,0 persen anak ditemukan mengalami gangguan emosi dan perilaku kategori tinggi.

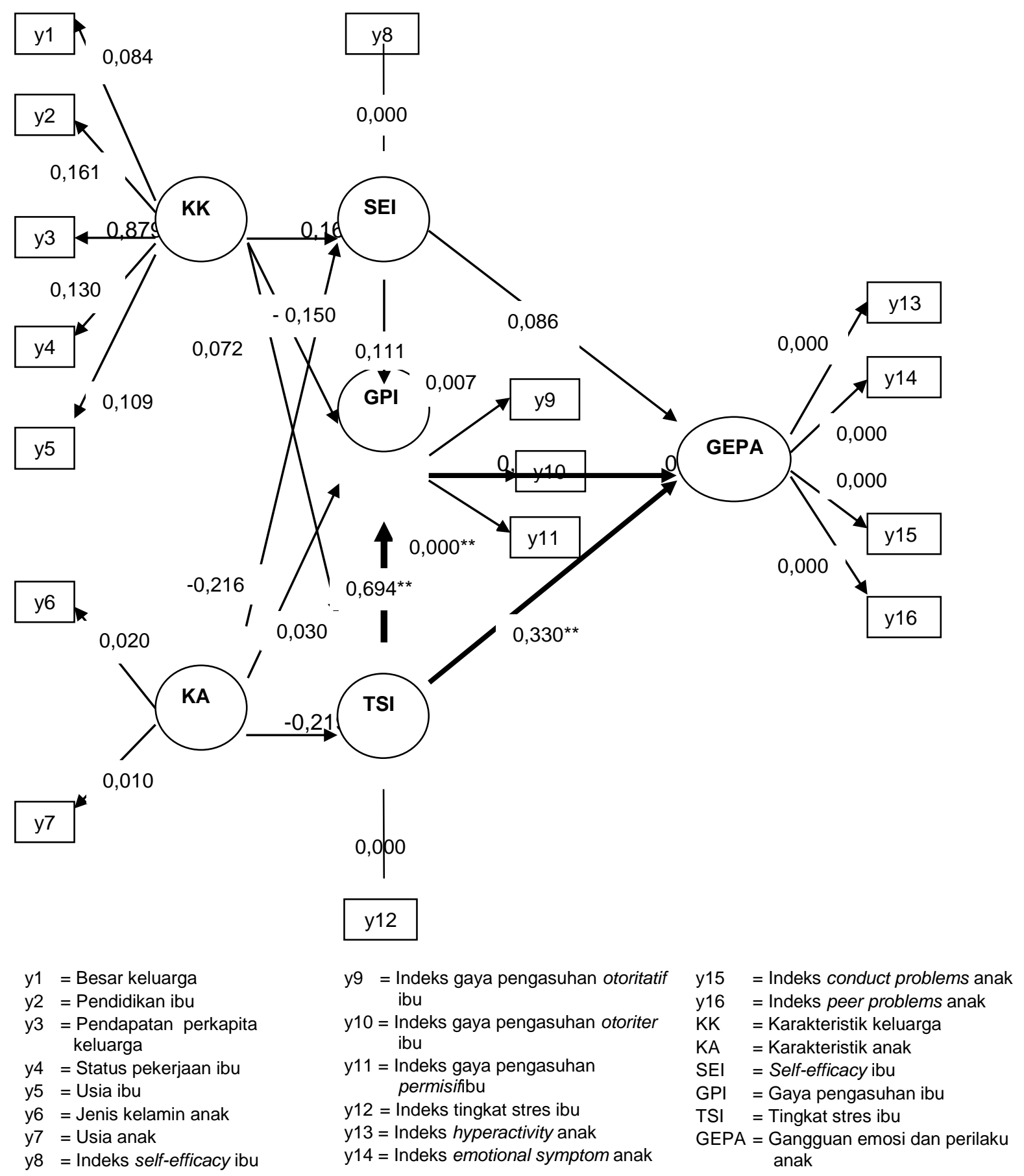

Gambar 1 Hasil model pengaruh karakteristik ibu, karakteristik anak, self efficacy ibu, gaya pengasuhan, dan tingkat stres ibu terhadap gangguan emosi dan perilaku anak 
Pada dimensi conduct problems menunjukkan bahwa anak dengan gangguan emosi dan perilaku kategori rendah sebesar 65,0 persen, anak dengan gangguan emosi dan perilaku kategori sedang 33,0 persen dan hanya 2,0 persen anak yang ditemukan mengalami gangguan emosi dan perilaku dengan kategori tinggi. Pada dimensi peer problem menunjukkan bahwa anak dengan gangguan emosi dan perilaku kategori rendah sebesar 68,0 persen, anak dengan gangguan emosi dan perilaku kategori sedang 27,0 persen dan tidak ditemukan anak yang mengalami gangguan emosi dan perilaku dengan kategori tinggi (Tabel 2).

\section{Pengaruh Self-Efficacy lbu, Gaya Pengasuhan Ibu, dan Tingkat Stres Ibu terhadap Gangguan Emosi dan Perilaku Anak}

Gangguan emosi dan perilaku anak merupakan outcome dalam penelitian ini. Model yang disusun dalam penelitian ini untuk melihat seberapa besar pengaruh variabel-variabel yang disusun terhadap gangguan emosi dan perilaku anak. Hasil analisis menggunakan smart PLS menunjukkan bahwa faktor-faktor yang berpengaruh terhadap gangguan emosi dan perilaku anak adalah gaya pengasuhan otoriter ibu, gaya pengasuhan permisif ibu, dan tingkat stres ibu. Self-efficacy ibu tidak berpengaruh terhadap gaya pengasuhan otoriter ibu ( $\beta=0,111 ; p=0,125)$, self-efficacy ibu juga tidak berpengaruh terhadap gangguan emosi dan perilaku anak $(\beta=0,086 ; p=0,096)$. Gaya pengasuhan otoritatif ibu tidak berpengaruh terhadap gangguan emosi dan perilaku anak $(\beta=0,613 ; \quad p=0,077)$. Gaya pengasuhan otoriter ibu berpengaruh sangat signifikan positif terhadap gangguan emosi dan perilaku anak $(\beta=0,613 ; \quad p=0,000)$. Gaya pengasuhan permisif ibu berpengaruh sangat signifikan positif terhadap gangguan emosi dan perilaku anak $(\beta=0,613 ; p=0,000)$. Tingkat stres ibu berpengaruh sangat signifikan positif terhadap gaya pengasuhan otoriter ibu $(\beta=0,694 ; p=0,000)$, tingkat stres ibu juga berpengaruh signifikan positif terhadap gangguan emosi dan perilaku anak $(\beta=0,330$; $p=0,000$ ) (Tabel 3, Gambar 1).

\section{PEMBAHASAN}

Bandura (1977) mendefinisikan self-efficacy sebagai keyakinan tentang kemampuan yang dimiliki untuk mengatur dan melakukan serangkaian tindakan yang diperlukan dalam mencapai keinginannya. Pada penelitian ini, 9 dari 10 ibu responden memiliki self-efficacy yang terkategori rendah yang berarti selfefficacy yang dimiliki ibu kurang baik. Menurut Bandura (1977), self-efficacy dipengaruhi oleh empat factor yaitu penguasaan pengalaman pribadi, pengalaman orang lain, persuasi verbal, dan reaksi fisiologis. Penguasaan pengalaman pribadi merujuk pada keberhasilan atau prestasi individu sebelumnya dalam menyelesaikan tugas dan dianggap memiliki pengaruh terkuat dan paling konsisten dalam self-efficacy (Schunk \& Meece, 2006). Pengalaman orang lain, merupakan suatu bentuk perbandingan sosial yang terjadi ketika individu lainnya mengikuti atau melakukan perilaku tertentu. Penelitian sebelumnya menunjukkan bahwa role model memiliki dampak yang kuat pada self-efficacy, ketika dihadapkan dengan masalah maka model yang memiliki kemiripan dengan individu dapat menunjukkan cara mengatasi atau adaptasi (Schunk, Hanson, \& Cox, 1987; Schunk \& Meece, 2006). Persuasi verbal dalam bentuk motivasi dari orang lain seperti orang tua, guru, dan teman sebaya, ditemukan memiliki dampak yang positif terhadap self-efficacy seseorang (Schunk \& Meece, 2006). Menurunnya selfefficacy orang tua dikaitkan dengan ketidakberfungsian pengasuhan yang tinggi, termasuk kelalaian dan reaktivitas yang berlebihan (Sanders \& Woolley, 2005), tingkat depresi ibu yang lebih tinggi, dan tingkat kepuasan orang tua yang lebih rendah (Dowling, 2014).

Self-efficacy orang tua dalam pengasuhan berkaitan dengan distres orang tua (Hastings \& Brown, 2002; Scheel \& Rieckmann, 1998; Shumow \& Lomox, 2002), keterampilan orang tua (Coleman \& Karraker, 2000; Scheel \& Rieckmann, 1998), dan perilaku anak (Teti et al., 1996; Woolfson et al., 2011). Self-efficacy ibu dalam penelitian ini tidak berpengaruh terhadap gaya pengasuhan dan gangguan emosi dan perilaku anak. Hasil penelitian ini tidak sejalan dengan penelitian Shaw dan Bell (1993) yang mengungkapkan bahwa orang tua dengan self-efficacy yang rendah akan mudah putus asa dalam mengasuh anaknya dan mungkin memburuk dari waktu ke waktu, yang mengarah ke peningkatan masalah perilaku pada anak-anak.

Hastuti (2015) menjelaskan bahwa gaya pengasuhan adalah cara berinteraksi orang tua-anak, paling menonjol, dan paling dominan dalam berhubungan dengan anak. Pada penelitian ini, 6 dari 10 ibu responden menerapkan gaya pengasuhan otoritatif, di samping menerapkan gaya pengasuhan otoriter dan permisif, yang berarti ibu dapat melakukan 
pengasuhannya dengan optimal. Optimalnya pengasuhan ibu dapat terjadi karena status sosial ekonomi keluarga terkategori cukup baik dan besar keluarga yang termasuk keluarga kecil.

Tingkat stres yang dimiliki orang tua terkadang menjadi faktor yang memengaruhi gaya pengasuhan orang tua. Pada penelitian ini, 3 dari 10 ibu responden mengalami tingkat sres terkategori tinggi, yang berarti ibu memiliki stres dan tekanan hidup yang tinggi. Hasil penelitian menunjukkan bahwa anak dari ibu responden yang mengalami tingkat sres terkategori tinggi ini mengalami gangguan emosi dan perilaku seperti hyperactivity, emotional symptoms, conduct problems, dan peer problems. Baker et al. (2001) mengungkapkan bahwa keadaan stres berkaitan dengan pengasuhan dan ketidakmampuan yang dimiliki orang tua. Abidin (1992) mengungkapkan bahwa tiga domain utama stres yang menyebabkan stres dalam pengasuhan, yaitu karakteristik anak, karakteristik keluarga dan situasi demografi stres kehidupan. Karakteristik anak meliputi kemampuan anak dalam beradaptasi, level hiperaktivitas, tuntutan anak, dan temper tantrum. Karakteristik orang tua mencakup level depresi, sikap terhadap anak dan keterampilan dalam mengasuh anak. Situasi demografi kehidupan meliputi, pergantian pekerjaan, pernikahan dan perceraian, serta anggota keluarga (mencakup kematian dan dukungan anggota keluarga).

Gaya pengasuhan otoriter dan gaya pengasuhan permisif ibu berpengaruh signifikan positif terhadap gangguan emosi dan perilaku anak yang berarti ibu yang melakukan pengasuhan dengan cara otoriter dan permisif akan meningkatkan gangguan emosi dan perilaku anak. Hal ini dikarenakan ibu dalam pengasuhannya menuntut anak secara berlebihan dan tidak peduli terhadap perilaku anak. Pengasuhan yang kurang tepat dapat berdampak pada anak lebih rentan mengalami masalah perkembangan, salah satunya gangguan emosi dan perilaku anak. Penelitian Zhou et al. (2004) menunjukkan bahwa anak yang diasuh dengan gaya pengasuhan otoriter akan memiliki kemampuan sosial dan kepercayaan diri yang rendah. Hasil penelitian ini sejalan juga dengan Covell dan Howe (2008) yang mengungkapkan bahwa perlakuan yang salah terhadap anak membuat anak berisiko mengalami masalah perkembangan, seperti gangguan emosi dan perilaku.

Tingkat stres ibu berpengaruh signifikan positif terhadap gaya pengasuhan otoriter ibu, yang berarti semakin tinggi stres yang dihadapi ibu maka ibu akan lebih sering melakukan pengasuhan otoriter. Tingkat stres ibu juga berpengaruh signifikan positif terhadap gangguan emosi dan perilaku anak yang berarti ibu yang mengalami stres dan tekanan yang cukup tinggi berpeluang akan meningkatkan gangguan emosi dan perilaku anak. Hal ini dikarenakan usia ibu yang terkategori dewasa madya belum cukup berpengalaman dalam mengasuh anak sehingga dapat memengaruhi emosi dan pikiran orang tua dan menjadikan anak sebagai objek pelampiasan dari emosi orang tua. Ketidakmampuan orang tua dalam mengelola stres dengan baik akan mengakibatkan stres yang dialami ibu berdampak pada anak yang dapat mengubah perilaku anak. Hasil penelitian ini sejalan dengan penelitian Anthony et al. (2005); Coyl et al. (2002); Crnic et al. (2005); Deater-Deckard (2005); Dopke et al. (2003); Yeo dan Teo (2013) yang mengungkapkan bahwa tingkat stres yang dialami oleh seorang ibu akan berpengaruh terhadap perkembangan emosi dan perilaku anak.

Penelitian ini juga menemukan tingkat stres ibu berpengaruh tidak langsung terhadap gangguan emosi dan perilaku anak melalui gaya pengasuhan yang berarti ibu yang mengalami stres dan tekanan yang cukup tinggi akan memengaruhi gaya pengasuhan ibu yang akan berdampak terhadap gangguan emosi dan perilaku anak. Hal ini disebabkan oleh kurangnya pengetahuan ibu mengenai stres dan dampaknya terhadap pengasuhan. Baker et al. (2001) mengungkapkan bahwa keadaan stres berkaitan dengan pengasuhan dan ketidakmampuan yang dimiliki orang tua. Penelitian ini sejalan dengan Gunarsa (2008) yang mengungkapkan bahwa stres dapat mengubah perilaku pengasuh, perilaku tersebut dapat berupa pengasuh yang baik pengabaian bahkan perilaku kasar yang kemudian memengaruhi emosi dan perilaku anak.

\section{SIMPULAN DAN SARAN}

Pada penelitian ini, hampir seluruh ibu responden memiliki self-efficacy yang terkategori rendah. Sebanyak enam dari sepuluh ibu respoden menerapkan gaya pengasuhan otoritatif, di samping menerapkan gaya pengasuhan otoriter dan permisif. Sebanyak tiga dari sepuluh ibu responden memiliki tingkat stres terkategori tinggi dan tujuh dari sepuluh anak memiliki gangguan emosi dan perilaku terkategori rendah. Hasil uji pengaruh menunjukkan bahwa self-efficacy ibu tidak berpengaruh terhadap gaya pengasuhan 
otoriter ibu, self-efficacy ibu juga tidak berpengaruh terhadap gangguan emosi dan perilaku anak. Gaya pengasuhan otoritatif ibu tidak berpengaruh terhadap gangguan emosi dan perilaku anak. Gaya pengasuhan otoriter dan gaya pengasuhan permisif ibu berpengaruh signifikan positif terhadap gangguan emosi dan perilaku anak. Tingkat stres ibu berpengaruh signifikan positif terhadap gaya pengasuhan otoriter ibu dan berpengaruh signifikan positif terhadap gangguan emosi dan perilaku anak. Temuan ini menegaskan bahwa gaya pengasuhan otoriter dan permisif serta tingkat stress ibu merupakan faktor resiko terhadap gangguan emosi dan perilaku anak pada anak usia sekolah.

Saran yang diberikan dalam penelitian ini untuk mencegah risiko gangguan gangguan emosi dan perilaku anak adalah gaya pengasuhan otoritatif ibu perlu ditingkatkan dan menghindari gaya pengasuhan otoriter dan permisif. Selain itu, ibu perlu menghindari tingkat stres ibu karena dapat memengaruhi gaya pengasuhan ibu dan berdampak buruk pada gangguan emosi dan perilaku anak. Selain itu, berdasarkan hasil penelitian ini juga menunjukkan perlu adanya edukasi, sosialisasi dan program pembinaan kepada anak dan orang tuanya mengingat adanya faktor resiko yang ditemukan pada orang tua khususnya gaya pengasuhan otoriter dan permisif serta tingkat stress ibu; sehingga dapat mencegah anak terpapar dari perilaku gangguan emosi dan perilaku yang berisiko terhadap perilaku dan kualitas anak dimasa depan. Penelitian selanjutnya disarankan untuk dapat melakukan penelitian tentang pengaruh peer group atau guru terhadap gangguan emosi dan perilaku anak karena permasalahan yang dihadapi oleh anak sangat kompleks.

\section{DAFTAR PUSTAKA}

[BPS] Badan Pusat Statistik. (2016). Indeks Pembangunan Manusia tahun 2016. Berita Resmi Statistik [internet]. 4 Januari 2016, [diunduh 2016 September 7]. Tersedia pada: http:// bps.go.id.

[KPAl] Komisi Perlindungan Anak Indonesia. (2015). Kekerasan terhadap Anak tiap Tahun Meningkat. Berita Resmi KPAl [internet]. 14 Juni 2015 [diunduh 2016 September 7]. Tersedia pada: http://www.kpai.go.id.

Abidin, R. R. (1992). The determinants of parenting behavior. Journal of Clinical Child Psychology, 21(4), 407412. doi:10.1207/s15374424jccp2104_12.
Anthony, L. G., Anthony, B. J., Glanville, D. N., Naiman, D. Q., Waanders, C., \& Shaffer, S. (2005). The relationships between parenting stress, parenting behaviour and preschoolers' social competence and behaviour problems in the classroom. Infant and Child Development: An International Journal of Research and Practice, 14(2), 133-154.

Baker, C. K., Perilla, J. L., \& Norris, F. H. (2001). Parenting stress and parenting competence among latino men who batter. Journal of Interpersonal Violence, 16(11), 1139

1157. doi:10.1177/088626001016011003.

Bandura, A. (1977). Self-efficacy: Toward a unifying theory of behavioral change. Psychological Review, 84(2), 191215. doi:10.1037/0033-295x.84.2.191.

Baumrind, D. (1966). Effects of authoritative parental control on child behavior. Child Development, 37(4), 887-907. doi:10.2307/1126611.

Baumrind, D. (1967). Child care practices anteceding three patterns of preschool behavior. Genetic monographs, 75(1), 43-88.

psychology

Benjet, C., Borges, G., \& Medina-Mora, M. E. (2010). Chronic childhood adversity and onset of psychopathology during three life stages: childhood, adolescence, and adulthood. Journal of psychiatric research, 44(11) 732-740. doi:10.1016/j.jpsychires.2010.01.004.

Braza, P., Carreras, R., Muñoz, J. M., Braza, F., Azurmendi, A., Pascual-Sagastizábal, E., ... \& Sánchez-Martín, J. R. (2015). Negative maternal and paternal parenting styles as predictors of children's behavioral problems: Moderating effects of the child's sex. Journal of Child and Family Studies, 24(4), 847-856.

Covell, K., \& Howe, R. B. (2008). Children, families and violence: Challenges for children's rights. Jessica Kingsley Publishers Limited.

Coyl, D. D., Roggman, L. A., \& Newland, L. A. (2002). Stress, maternal depression, and negative mother-infant interactions in relation to infant attachment. Infant Mental Health Journal: Official Publication of The World Association for Infant Mental Health, 23(1-2), 145-163. doi:10. 1002/imhj.10009.

Crnic, K. A., Gaze, C., \& Hoffman, C. (2005). Cumulative parenting stress across the 
preschool period: Relations to maternal parenting and child behaviour at age 5. Infant and Child Development: An International Journal of Research and Practice, 14(2), 117-132. doi:10.1002/icd.384.

Deater-Deckard, K. (2005). Parenting stress and children's development: Introduction to the special issue. Infant and Child Development, 14(2),111-115. doi:10.1002/icd.383.

Dopke, C. A., Lundahl, B. W., Dunsterville, E., \& Lovejoy, M. C. (2003). Interpretations of child compliance in individuals at high-and low-risk for child physical abuse. Child Abuse \& Neglect, 27(3), 285-302. doi:10.1016/S0145-2134(03)00007-3.

Dowling, H. (2014). Parental self-efficacy in early years parenting (Doctoral dissertation). Manchester, US: University of Manchester.

Forness, S. R., \& Knitzer, J. (1990). A new proposed definition and terminology to replace "serious emotional disturbance" in education of the handicapped act. Washington, US: The National Mental Health and Special Education Coalition.

Goodman, R., Meltzer, H., \& Bailey, V. (2003). The strengths and difficulties questionnaire: A pilot study on the validity of the self-report version. International Review of Psychiatry, 15(1-2), 173-177. doi:10.1080/0954026021000046137.

Gunarsa, S. D. (2008). Psikologi perkembangan anak dan remaja. Jakarta, ID: PT BPK Gunung Mulia.

Hastings, R. P., \& Brown, T. (2002). Behavior problems of children with autism, parental self-efficacy, and mental health. American Journal on Mental Retardation. 107(3), 222-232. doi:10.1352/08958017(2002)107<0222:BPOCWA>2.0.CO;2

Hastuti, D. (2015). Pengasuhan: Teori dan prinsip serta aplikasinya di Indonesia. Bogor, ID: IPB Press.

Hickman, L. J. (2013). How much does "how much" matter? Assessing the relationship between children's lifetime exposure to violence and trauma symptoms, behavior problems, and parenting stress. Journal of interpersonal violence, 28(6), 1338-1362. doi:10.1177/0886260512468239.

Isfandari, S., \& Suhardi, S. (1997). Gejala gangguan mental emosional pada anak. Jakarta, ID: Buletin Penelitian Kesehatan

Jones, T. L., \& Prinz, R. J. (2005). Potential roles of parental self-efficacy in parent and child adjustment: A review. Clinical psychology review, 25(3), 341-363. doi: 10.1016/j.cpr.2004.12.004.

Kessler, R. C., Andrews, G., Colpe, L. J., Hiripi, E., Mroczek, D. K., Normand, S. L., ... \& Zaslavsky, A. M. (2002). Short screening scales to monitor population prevalences and trends in non-specific psychological distress. Psychological medicine, 32(6), 959-976.

Lorber, M. F., \& Egeland, B. (2011). Parenting and infant difficulty: Testing a mutual exacerbation hypothesis to predict early onset conduct problems. Child Development, 82(6), 20062020. doi:10.1111/j.14678624.2011.01652.x.

Mäntymaa, M., Puura, K., Luoma, I., Latva, R., Salmelin, R. K., \& Tamminen, T. (2012). Predicting internalizing and externalizing problems at five years by child and parental factors in infancy and toddlerhood. Child Psychiatry \& Human Development, 43(2), 153-170.

Morawska, A., Sanders, M. R., Haslam, D., Filus, A., \& Fletcher, R. (2014). Child adjustment and parent efficacy scale: Development and initial validation of a parent report measure. Australian Psychologist, 49(4), 241252. doi:10.1111/ap.12057.

Okorodudu, G. N. (2010). Influence of parenting styles on adolescent delinquency in delta central senatorial district. Edo Journal of Counselling, 3(1), 58-86. doi:10.4314/ejc.v3i1.52682.

Page, M., Wilhelm, M. S., Gamble, W. C., \& Card, N. A. (2010). A comparison of maternal sensitivity and verbal stimulation as unique predictors of infant socialemotional and cognitive development. Infant Behavior and Development, 33(1), 101-110. doi: 10.1016/j.infbeh.2009.12.001.

Penza, K. M., Heim, C., \& Nemeroff, C. B. (2003). Neurobiological effects of childhood abuse: Implications for the pathophysiology of depression and anxiety. Archives of women's mental health, 6(1), 15-22. doi:10.1007/s00737002-0159-x. 
Rice, P. L. (1992). Stress and health (2nd Ed). California, US: Wadsworth.

Robinson, C. C., Mandleco, B., Olsen, S. F., \& Hart, C. H. (1995). Authoritative, authoritarian, and permissive parenting practices: Development of a new measure. Psychological Reports, 77(3), 819830. doi:10.2466/pr0.1995.77.3.819.

Rothbart, M. K. (2004). Commentary: Differentiated measures of temperament and multiple pathways to childhood disorders. Journal of Clinical Child and Adolescent Psychology, 33, 82-87. doi.org/10.1207/S15374424JCCP3301_8.

Sanders, M. R., \& Woolley, M. L. (2005). The relationship between maternal self-efficacy and parenting practices: Implications for parent training. Child: Care, Health and Development, 31(1), 6573. doi:10.1111/j.1365-2214.2005.00487.x

Scheel, M. J., \& Rieckmann, T. (1998). An empirically derived description of selfefficacy and empowerment for parents of children identified as psychologically disordered. American Journal of Family Therap, 26(1), 15-27. doi:10.1080/01926189808251083.

Schunk, D. H., \& Meece, J. L. (2006). Selfefficacy development in adolescence. Selfefficacy beliefs of adolescents, 5, 71-96.

Schunk, D. H., Hanson, A. R., \& Cox, P. D. (1987). Peer-model attributes and children's achievement behaviors. Journal of Educational Psychology, 79(1), 54. doi:10.1037/0022-0663.79.1.54.

Shaw, D. S., \& Bell, R. Q. (1993). Developmental theories of parental contributors to antisocial behavior. Journal of abnormal child psychology, 21(5), 493518. doi:10.1007/BF00916316.
Shumow, L., \& Lomax, R. (2002). Parental efficacy predictor of parenting behavior and adolescent outcomes. Parenting: Science and Practice, 2(2), 127-150. doi:10.1207/S15327922PAR0202_03.

Teti, D. M., O'Connell, M. A., \& Reiner, C. D. (1996). Parenting sensitivity, parental depression and child health: The mediational role of parental self-efficacy. Infant and Child Development, 5(4), 237250. doi:10.1002/(SICI)10990917(199612)5:4<237::AIDEDP136>3.0.CO;2-5.

Woolfson, L. M., Taylor R. J., \& Mooney L. 2011. Parental attributions of controllability as a moderator of the relationship between developmental disability and behaviour problems. Child: Care, Health and Development, 37(2), 184-194. doi:10.1111/j.1365-2214.2010.01103.x.

Yeo, K. J., \& Teo, S. L. (2013). Child behavior and parenting stress between employed mothers and at home mothers of preschool children. Procedia-Social and Behavioral Sciences, 90, 895-903. doi:10.1016/j.sbspro.2013.07.166.

Yimer, M., Abera, B., Mulu, W., \& Bezabih, B. (2014). Knowledge, attitude and practices of high risk populations on louse-borne relapsing fever in Bahir Dar city, north-west Ethiopia. Science Journal of Public Health, 2(1), 15-22. doi:10.11648/j.sjph.20140201.13.

Zhou, Q., Eisenberg, N., Wang, Y., \& Reiser, M. (2004). Chinese children's effortful control and dispositional anger/frustration: Relations to parenting styles and children's social functioning. Developmental psychology, 40(3), 352. doi:10.1037/00121649.40.3.352. 